\title{
Preservation of fresh hoar semen. Fertility trials with two extenders
}

\author{
IF. BARITIAUU, J. BISSSIERL*, M. COUROT* \\ Station expérimentale d'Insémination artificielle, \\ 86480 Rouille \\ * Station de Recherches sur la Plysiologie de la Reproduction, I. N. R. A., \\ Contre de Rccherches do Tours, \\ B.P. 1, Nouzilly, 37380 Monnaie
}

Two extenders have been tested for preservation of boar semen. Immediately after semen collection and examination, split ejaculates were diluted with BL I or I.V.T. without $\mathrm{CO}_{2}, 3 \cdot \mathrm{IO}^{9}$ $\mathrm{spz} /$ close of $35 \mathrm{ml}$, and maintained at $+15^{\circ} \mathrm{C}$ in sealed glass-ampoules. The number of motile sperm decreased more rapidly with I.V.T. than with B.L. I. The 54 -day-non return of the sows and gilts was the same for both diluents when inseminations were done on the day of semen collection. The day after, the NR decrease with I.V.T. and two doses of semen/I.A. were necessary to maintain fertility. Alter this period, the results were not satisfactory. With B.L. I cxtender, fertility was maintained on the day after semen collection ; it began to decrease on the third day, but could be maintained with two doses of semen.

B.L. I extender preserved boar semen longer than I.V.T. did. This would be useful for practical use with groups of sows programmed for A.I.

\section{Comparison of three methods for hormonal synchronisation of heats in gilts during late fattening. Use of P.M.S. and II.C.G.}

\author{
C. TEXIER, J.-C. UHLEN, A. MALITTE \\ Institut Technique du Porc, Service Bâtiment et Environn'ment, \\ 149 , rue de Bercy, \\ i5579 Paris Cedex 12 \\ Service Conduite d'élevage, Service Sélection, \\ La Motte au Vicomte, B.P. 3, 35650 Le Rhen
}

Early mating of sows, at least one month before the normal date of slaughter is difficult to practise in a pig fattening house. $\Lambda$ s this technique may primarily interest pig feeders, it is consequently logic to apply to artificial insemination.

Thus, any technique allowing synchronisation of heats in prepuberal gilts is interesting. As our first trial on early incluction of puberty by "natural " methods (mixing of animals, transport, 
feed restriction...) did not give any positive results, we applied to injection of hormone such as P.M.S. and H.C.G. The results of this study show the favourable effect of hormonal treatments : systematic insemination of the sows before $100 \mathrm{~kg}$ (at age of 7 months) on day 4 and 5 after injection of 400 units of PMS and 200 units of HCG led to obtention of 26 p. Ioo pregnant sows and a mean number of foetuses exceeding 9 at 30 days of gestation. These results seem to be poor as compared to those obtained by SCHILLING in 1972 , but they have the advantage of supplying the minimum rate of conception to be expected in practise.

\title{
Fertility and prolifieacy of sows inseminated with frozen semen : efiect of the moment of insemination
}

\author{
M. PAQUigNON, C. DELAHAYE, J. BUSSIERE*, M. COUROT* \\ Institut Technique du Porc, \\ 149, rue de Bercy, \\ 75579 Paris Cedex 19 \\ Société Sanders, Centre expérimental de Sourches, \\ 72480 Bernay-en-Champagne \\ * Laboratoire de Physiologie de la Reproduction, \\ Centre de Recherches de Tours, I. N. R. A., \\ B. P. 1, Nouzilly, 37380 Monnaie
}

Various experiments were made in order to determine the optimum moment for insemination in the case of heat detection once per day by means of a teasor boar and in order to estimate fertility and prolificacy results of the sows checked for oestrus by the farmer. The best results (65-70 p. Ioo pregnant sows) were obtained when inseminations with frozen semen were realized 24 hours after the presumed onset of heats. Prolificacy was slightly lower than that obtained after insemination with fresh semen. 